\title{
Impact of Forcing Summer Asparagus in Coastal South Carolina on Yield, Quality, and Recovery from Harvest Pressure
}

\author{
Robert J. Dufault ${ }^{1}$ \\ Coastal Research and Education Center, Department of Horticulture, Clemson University, 2865 Savannah \\ Highway, Charleston, SC 29414 \\ Additional index words. Asparagus officinalis, crown, stands, harvest stress
}

\begin{abstract}
The objective of this study was to determine the effect of forcing summer asparagus (May to October) and age at first harvest after transplanting on yield and quality. Ten-week-old ' $U \mathrm{C} 157 \mathrm{~F}$ ' asparagus seedlings were field-planted on Sept. 1986 and forced to emerge from 1988 to 1992 by mowing fern in separate replicated plots in May, June, July, August, September, or October. Forcing treatments were not spring-harvested. Forced yields were compared to normal spring harvests (emerging from January to April). Harvesting began for the first time $\approx 18$ or 30 months after transplanting. Spring 1988 yields were greatest of all, but declined yearly for 5 years. Summer forcing in either July or August maintained acceptable yields through 1992. The warmer climate during summer forcing caused most plants to reach the prescribed cutting pressure (eight spears per plant) within a standard 6-week harvest season. Cooler temperatures during spring harvest seasons slowed spear emergence and prevented the plants from reaching prescribed cutting pressure. Forcing in May and June was too stressful to plant recovery after the harvest season by reducing fern regrowth and increasing plant death. Cooler temperatures during October forcing inhibited spear emergence. Forcing in September yielded less than forcing in July and August, but September asparagus would command higher market prices. There was no advantage at any harvest time to delay first harvests from 18 to 30 months after transplanting. Forcing in July through September has potential as an alternative enterprise in coastal South Carolina.
\end{abstract}

Large-scale, domestic production of asparagus begins in the desert valleys of California in January and ends in late June in Michigan and Washington. Thereafter, domestic production for fresh asparagus diminishes and imports from Mexico and South America dominate until the cycle begins again in January. Therefore, from July to December, a market window exists for areas with subtropical climates, such as coastal South Carolina, to force fresh market asparagus.

The onset of spear emergence is basically determined by soil temperature. In spring, asparagus begins to emerge at minimum/ maximum soil temperatures of $\approx 14 / 18 \mathrm{C}$ (Dufault, 1994). If in the spring asparagus spears are not harvested and allowed to "fern out," the asparagus fern can be mowed in mid- to late-summer; if the soil temperatures are high, spear production will occur.

The idea of summer-fall asparagus harvesting is not a new concept. Although very little work has been done on asparagus forcing, regional research studies have been reported in Mississippi (Farish, 1937), central South Carolina (Scott et al., 1939), Delaware (Brasher, 1956), Canada (Jasmin and Laliberte, 1962), and Mexico (Campbell Institute of Agricultural Research, 1970). Generally, these studies indicated that forcing has potential in areas with long growing seasons, but spear quality was inferior to traditional spring production. Poor spear size can be related to low carbohydrate status in the storage root systems (Scott et al., 1939). Twice-a-year harvesting in spring and fall reduced the time required to replenish carbohydrate reserves before winter dormancy (Brasher, 1956). Other problems encountered with forcing asparagus include spear tip feathering and unacceptable stand reduction (Jasmin and Laliberte, 1962). Practical cultural systems to sur-

Received for publication 6 July 1993. Accepted for publication 21 Oct. 1993. Technical contribution no. 3495 of the South Carolina Agricultural Experiment Station, Clemson Univ. The cost of publishing this paper was defrayed in part by the payment of page charges. Under postal regulations, this paper therefore must be hereby marked advertisement solely to indicate this fact.

${ }^{1}$ Associate professor. mount these problems with forcing were not developed by any of these researchers.

Asparagus is usually first harvested $\approx 36$ months after transplanting. Harvesting 1 year after transplanting, however, has been reported to reduce number, diameter, and total spear productivity (Lewis, 1934; Lloyd and McCollum, 1938). Conversely, other researchers have not reported any detrimental effects in yield or quality from harvesting 1 year after transplanting crowns (Benson and Motes, 1982; Jenkins, 1959; Jones and Robbins, 1926). Although early harvest is promising, all of these studies were performed on normal spring-harvested asparagus rather than summer-forced asparagus. The objective of this research was to combine earlier harvesting with summer-fall harvesting schedules into new cultural management methods to reduce the risk and increase the potential of forcing asparagus.

\section{Materials and Methods}

Ten-week-old ' $\mathrm{UC} 157 \mathrm{~F}_{1}$ ' asparagus seedlings were transplanted on level land $30 \mathrm{~cm}$ apart within double rows spaced $36 \mathrm{~cm}$ apart on 30 July 1986 . Each double row plot (considered a bed) was $6 \mathrm{~m}$ long, $1.8 \mathrm{~m}$ apart from bed center, and contained 41 transplants. The soil was a Yauhannah loamy fine sand (Aquic Hapludults). Each plot consisted of double test rows within a bed and was bordered on each side by double guard rows. In 1987, the soil was ridged $\approx 20 \mathrm{~cm}$ over the normal ground level before spear emergence and maintained at that height for 5 years. Standard commercial cultural practices were used during the course of the study (Cook, 1977).

The experiment was a factorial combination of two factors: 1) harvest season [normal spring emergence (can occur from January to April), May, June, July, August, September, October, or an unharvested control] and 2) age at first harvest (18 or 30 months after transplanting). The experimental treatments were replicated three times in a randomized block design. 
Plots destined for forcing were allowed to produce fern in the spring without any harvests. To force spears, all fern and stalks within the test and guard plots were cut to the ground during the first week of each forcing month. Fern from five randomly selected plants within each plot were weighed and stalks were counted to determine forcing's effect on recovery and biomass production. Plant stands within each plot were counted in spring each year $\approx 1$ month after first spear emergence.

Asparagus spears were harvested by cutting above the soil surface with a knife, and brightly painted wooden markers (coffee stirrers) were inserted into the soil next to cut stumps. Wooden markers were counted each harvest day and allowed easy accounting of actual harvest pressure per plant. At first harvest in 1988, a maximum of five spears was harvested from each plant. Harvests for individual plots were terminated if either 1) $80 \%$ of the plants within a plot produced five spears per plant or 2) 6 weeks had elapsed since fern mowing. Each plot was harvested three times weekly. From 1989 to 1992, a maximum of eight spears per plant was harvested from each plant and harvests were terminated for that plot if either 1) $80 \%$ of the plants produced eight spears per plant or 2) 6 weeks had elapsed since fern mowing. The number of plants within each plot that did not reach cutting pressure within the allotted time was recorded and converted to a percentage of the total number of plants present (from yearly spring stand counts).

Asparagus was graded into either marketable or cull quality categories based on U.S. Dept. of Agriculture (USDA) standards (USDA, 1977). Diameter of each marketable spear butt was measured and graded as large $(>1.3 \mathrm{~cm})$, medium $(0.8$ to $1.3 \mathrm{~cm})$, or small $(<0.8 \mathrm{~cm})$.

Randomly selected samples of storage root tissue were collected with a soil auger from each plot throughout the calendar year. From 1988 to 1992, the total yearly number of samples collected was eleven, eight, five, four, and three, respectively. The fructose content (Shelton and Lacy, 1980) was determined by the anthrone method (Morris, 1948). All data were pooled for each year to determine a yearly grand mean by harvest season. Root tissue was washed and dried for $48 \mathrm{~h}$ at $75 \mathrm{C}$. The dried samples were ground with an analytical mill (model A-10; Tekmar, Cincinnati) before analysis.

The data were subjected to analysis of variance (ANOVA) and means were separated by least significant difference if the F test was significant at $P=0.05$. The relative importance of harvest season and age at first harvest was determined by partitioning the total sum of squares for treatments into main and interaction effects and expressing these individual contributions to variation as a percentage of the sum of squares for the model (composed of only those sources of variation in the ANOVA).

\section{Results}

Yield vs. harvest season. Normal spring spear emergence varied yearly and occurred on 7 Mar. 1988, 18 Jan. 1989, 26 Jan. 1990, 4 Mar. 1991, and 26 Feb. 1992. Most variation in marketable yield in all years was assigned to the harvest season main effect, with negligible portions attributable to age at first harvest or interactions (Table 1).

The ranking of the most superior harvest season varied by harvest year. In 1988, spring harvests had the greatest marketable yields, with July forcing producing $13 \%$ less than normal spring production. Yields from the other forcing times were significantly lower (by percentage) than spring harvests in the following sequence: 1) August (28\%), 2) June and September (40\%), 3) May (54\%), and 4) October (87\%) (Fig. 1). In 1989, May to August forcings yielded similarly to the spring harvest. September forcing was terminated after seven harvests by Hurricane Hugo on 19 Sept. October forcings yielded $72 \%$ less than spring harvests and continued to yield poorly over the course of the field study because cool soil temperatures inhibited emergence. In 1990, May to September forcings yielded similarly to spring harvests, and spring yields progressively declined from 1988 to 1992 . The advantage of July forcing became apparent by 1991. Spring yields were $22 \%$ lower than July forcing and declined 53\% by 1992 . By 1991, May forcing proved to be too stressful, since yields were $51 \%$ and $61 \%$ lower than spring harvesting and July forcing, respectively. By the fifth and final year, spring yields were 64\% lower than August forcing. September forcing, although statistically similar to August forcing, was $19 \%$ less productive. July forcing still maintained acceptable yields, but was $25 \%$ less than August forcing.

Total yields summed over the 5-year period were statistically similar and greater for spring harvests and July forcing than all other harvest seasons (Fig. 2). July forcing yielded 9\% more than spring harvests. Forcing in August and June was 14\% and $18 \%$ less productive than July forcing. September, May, and October forcings had $29 \%, 44 \%$, and $77 \%$ lower total yields than spring harvesting, respectively. Therefore, forcing in July and August showed the least risk of all forcing seasons.

Age at first harvest did not affect yield status except in 1990, but only $12 \%$ of the variation in yield was attributed to this factor (Table 1). Therefore, first harvests of asparagus in coastal South Carolina should begin 18 months after transplanting and delaying first harvest to 30 months after transplanting is unwarranted.

Qualityvs. harvest season. Production of large-diameter spears indicated higher quality and plant vigor. Most variation in large spears was assigned to harvest season, with age at first harvest having no effect (Table 2). In 1988, July forcing produced more large-diameter spears than all other harvest seasons. June and August forcings yielded more large spears than spring harvesting, while September forcing was similar to spring. Few large spears emerged during May and October forcings. In 1989, there was no statistical difference in large spears among all harvest seasons, but, in 1990, June forcing produced the most large spears. From 1991 to 1992, the proportion of large spears decreased in spring harvests and in May, June, and October forcings. In 1992, July and August forcings yielded more large spears than all other harvest seasons.

Stand vs. harvest season. The ability of asparagus to recover from harvest pressure is partially indicated by declining plant populations over harvest years. The stands for all harvest seasons were similar from 1986 to 1989 (data not shown). A small portion of variation in stand from 1989 to 1991 was assigned to harvest season and age, yet most variation was due to uncontrolled error

Table 1. Influence of the experimental factors of harvest season and age at first harvest and their interactions on the total percentage of variation of marketable yield from 1988 to 1992.

\begin{tabular}{lcccccc}
\hline \multirow{2}{*}{$\begin{array}{l}\text { Source of } \\
\text { variation }\end{array}$} & \multicolumn{3}{c}{ Harvest year } & $\begin{array}{c}\text { Cumulative } \\
\text { yield from }\end{array}$ \\
\cline { 2 - 6 } & 1988 & 1989 & 1990 & 1991 & 1992 & $1988-92$ \\
\hline Rep & $7^{* * *}$ & $6^{* *}$ & 6 & 4 & $7^{* *}$ & 6 \\
Age (A) & --- & 0 & $12^{* *}$ & 0 & 1 & 3 \\
Season (S) & $88^{* *}$ & $64^{* *}$ & $50^{* *}$ & $73^{* *}$ & $77^{* *}$ & $70^{* *}$ \\
A $\times$ S & --- & 10 & 5 & 5 & 2 & 4 \\
Error & 5 & 20 & 27 & 18 & 13 & 17
\end{tabular}

${ }^{\mathrm{z}} \mathrm{Sum}$ of squares for each factor converted to a percentage of total sum of squares.

*,** Significant at $P=0.05$ or 0.01 , respectively. 


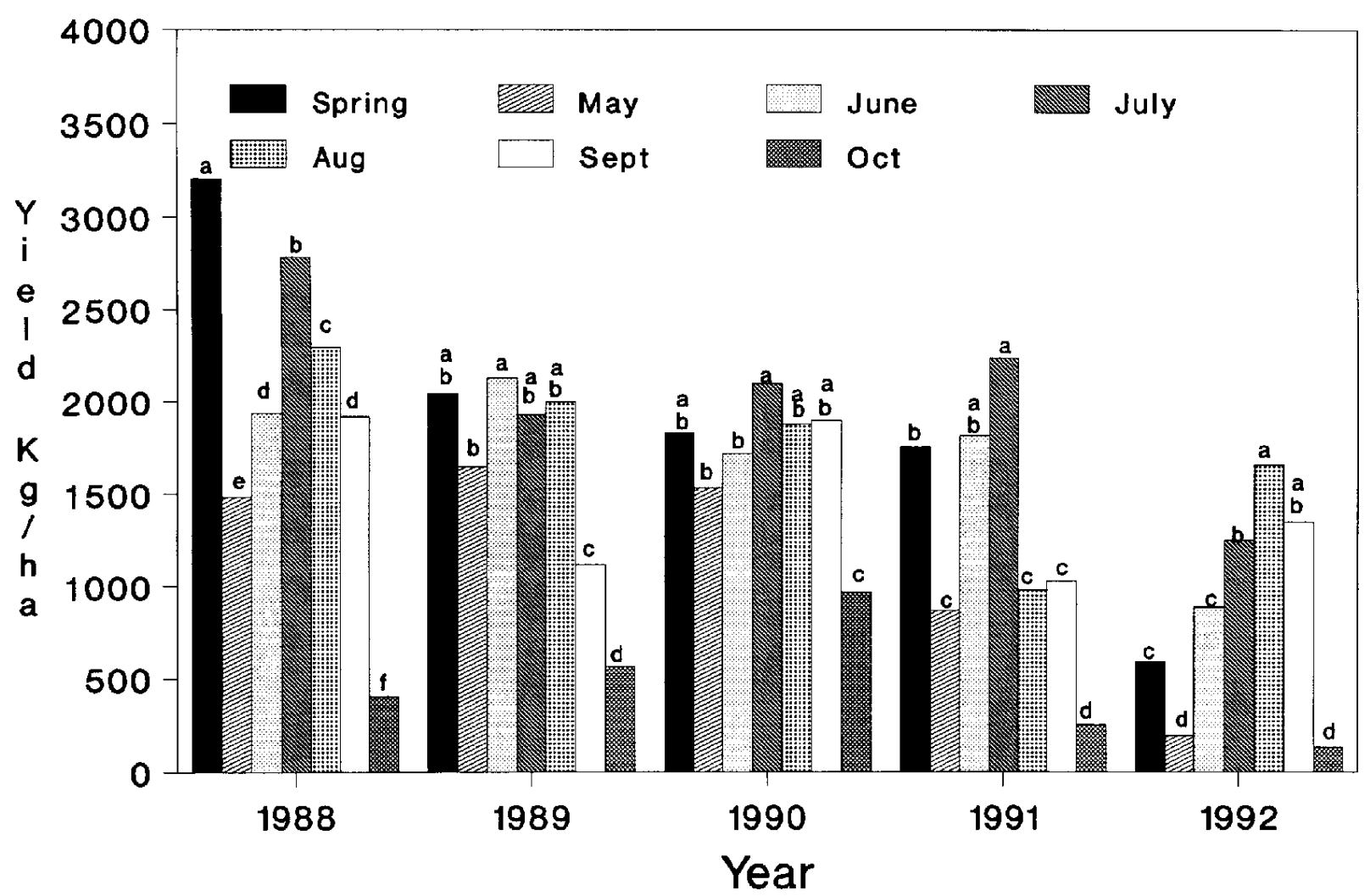

Fig. 1. Marketable yield of asparagus harvested in spring and forced in separate plots from May to October 1988 to 1992 . Bars within year with different letters are significant by LSD at $P=0.05$.

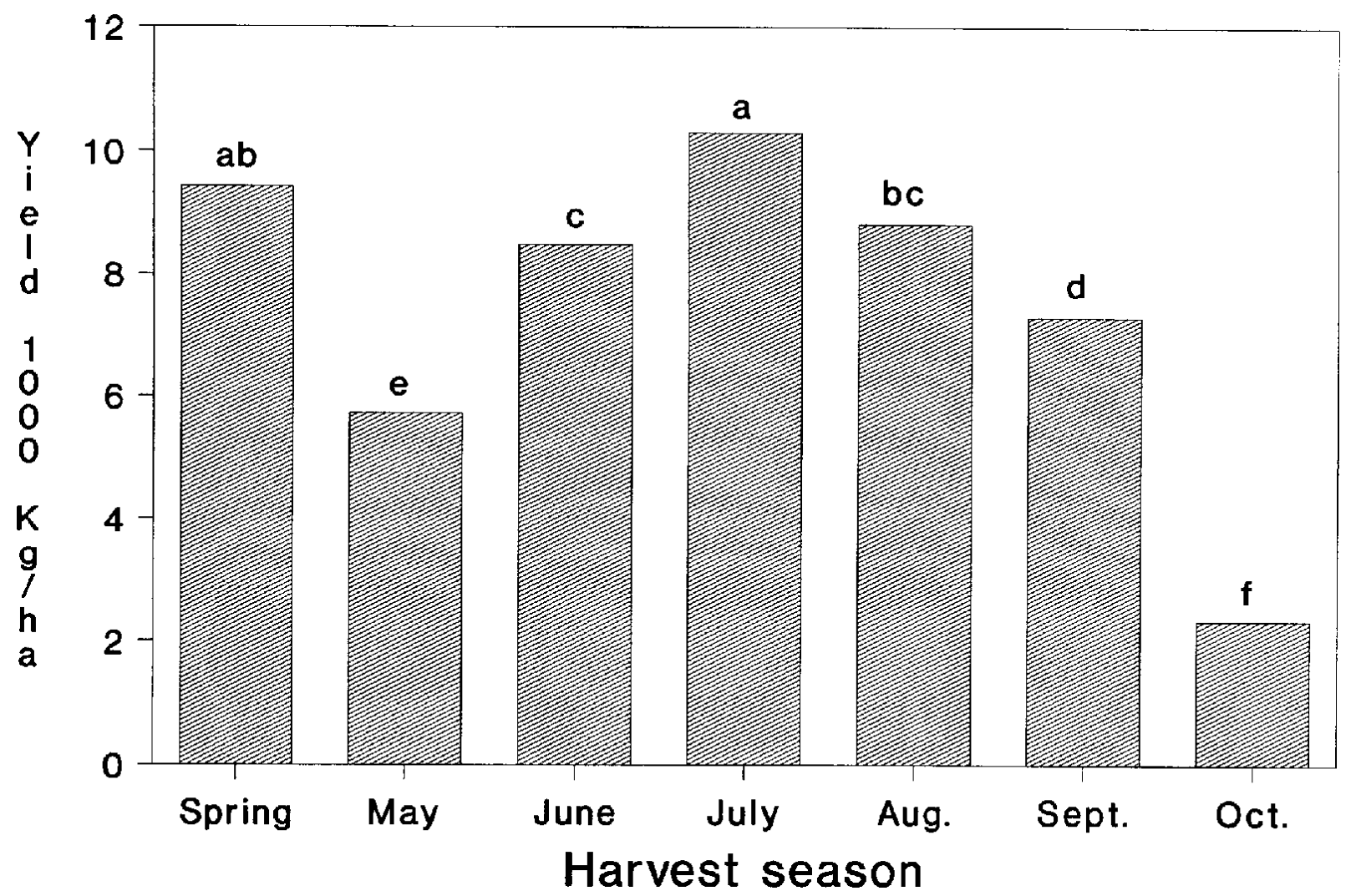

Fig. 2. Total cumulative marketable yield of asparagus harvested from 1988 to 1992 in spring and forced in separate plots from May to October. Bars with different letters are significant by LSD at $P=0.05$. 
Table 2. Influence of harvest season and age at first harvest on spear quality.

\begin{tabular}{|c|c|c|c|c|c|c|c|c|c|c|c|c|c|c|c|}
\hline \multirow{3}{*}{$\begin{array}{l}\text { Harvest } \\
\text { season }\end{array}$} & \multicolumn{15}{|c|}{ Spear diameter distribution $^{\mathrm{z}}(\%)$} \\
\hline & \multicolumn{3}{|c|}{1988} & \multicolumn{3}{|c|}{1989} & \multicolumn{3}{|c|}{1990} & \multicolumn{3}{|c|}{1991} & \multicolumn{3}{|c|}{1992} \\
\hline & $\mathrm{L}$ & M & $S$ & $\mathrm{~L}$ & M & $\mathrm{S}$ & $\mathrm{L}$ & M & $S$ & $\mathrm{~L}$ & M & $S$ & $\mathrm{~L}$ & M & $\mathrm{S}$ \\
\hline Spring & $4 c^{y}$ & $26 \mathrm{a}$ & $70 \mathrm{f}$ & $13 \mathrm{a}$ & $68 \mathrm{~b}$ & $19 \mathrm{c}$ & $9 \mathrm{~b}$ & $53 \mathrm{a}$ & $38 \mathrm{a}$ & $10 \mathrm{a}$ & $58 \mathrm{ab}$ & $32 \mathrm{c}$ & 2 cde & $42 \mathrm{bc}$ & $57 \mathrm{~b}$ \\
\hline May & $2 \mathrm{~d}$ & $26 \mathrm{a}$ & $72 \mathrm{e}$ & $10 \mathrm{a}$ & $57 \mathrm{~cd}$ & $33 \mathrm{ab}$ & $8 \mathrm{bc}$ & $52 \mathrm{a}$ & $40 \mathrm{a}$ & $2 \mathrm{c}$ & $31 \mathrm{c}$ & $67 \mathrm{a}$ & $1 \mathrm{de}$ & $24 \mathrm{c}$ & $75 \mathrm{a}$ \\
\hline June & $6 \mathrm{~b}$ & $20 \mathrm{~b}$ & $74 \mathrm{~d}$ & $7 \mathrm{a}$ & $62 \mathrm{c}$ & $31 \mathrm{~b}$ & $14 \mathrm{a}$ & $59 a$ & $27 \mathrm{~b}$ & $8 a b$ & $55 \mathrm{ab}$ & $37 \mathrm{bc}$ & $5 \mathrm{~cd}$ & $51 \mathrm{ab}$ & $44 \mathrm{c}$ \\
\hline July & $9 \mathrm{a}$ & $18 \mathrm{bc}$ & $73 \mathrm{~d}$ & $6 \mathrm{a}$ & $55 \mathrm{~d}$ & $39 \mathrm{a}$ & $9 \mathrm{~b}$ & $54 \mathrm{a}$ & $37 \mathrm{a}$ & $8 a b$ & $55 \mathrm{ab}$ & $37 \mathrm{bc}$ & $12 \mathrm{a}$ & $52 a b$ & $36 \mathrm{c}$ \\
\hline August & $7 \mathrm{~b}$ & $18 \mathrm{c}$ & $75 c$ & $5 \mathrm{a}$ & $80 \mathrm{a}$ & $15 \mathrm{c}$ & $5 \mathrm{bc}$ & $55 \mathrm{a}$ & $40 \mathrm{a}$ & $3 \mathrm{bc}$ & $49 \mathrm{~b}$ & $48 \mathrm{~b}$ & $10 \mathrm{ab}$ & $62 \mathrm{a}$ & $28 \mathrm{~d}$ \\
\hline September & $4 \mathrm{c}$ & $19 \mathrm{bc}$ & $77 \mathrm{~b}$ & $9 \mathrm{a}$ & $59 \mathrm{~cd}$ & $32 \mathrm{~b}$ & $4 \mathrm{c}$ & $55 \mathrm{a}$ & $41 \mathrm{a}$ & $4 \mathrm{bc}$ & $59 \mathrm{ab}$ & $37 \mathrm{bc}$ & $6 \mathrm{bc}$ & $55 a b$ & $39 c$ \\
\hline October & $0 \mathrm{e}$ & $4 d$ & $96 a$ & $13 \mathrm{a}$ & $68 \mathrm{a}$ & $19 \mathrm{c}$ & $4 \mathrm{c}$ & $54 \mathrm{a}$ & $42 \mathrm{a}$ & $3 c$ & $65 \mathrm{a}$ & $32 \mathrm{c}$ & $0 \mathrm{e}$ & $46 \mathrm{ab}$ & $54 \mathrm{~b}$ \\
\hline \multicolumn{16}{|c|}{ Age (months) at first harvest } \\
\hline 18 & --- & --- & --- & NS & $56 \mathrm{a}$ & $35 \mathrm{~b}$ & NS & $52 \mathrm{a}$ & $42 \mathrm{a}$ & NS & NS & NS & NS & NS & NS \\
\hline 30 & --- & --- & --- & NS & $68 \mathrm{~b}$ & $24 \mathrm{a}$ & NS & $57 \mathrm{~b}$ & $34 \mathrm{~b}$ & NS & NS & NS & NS & NS & NS \\
\hline \multicolumn{16}{|c|}{ Source of variation ${ }^{\mathrm{x}}$} \\
\hline Rep & 0 & $9^{*}$ & $7^{* *}$ & 0 & 3 & 2 & 0 & 1 & 0 & 6 & 1 & 2 & 6 & 0 & 1 \\
\hline Age (A) & --- & --- & --- & 0 & $21^{* *}$ & $18^{* *}$ & 2 & $21^{* *}$ & $17^{* * *}$ & 1 & 0 & 1 & 0 & 1 & 0 \\
\hline Season $(S)$ & $100^{* * *}$ & $82^{* *}$ & $87^{* * *}$ & 25 & $49^{* *}$ & $47^{* *}$ & $43^{* *}$ & 12 & $26^{*}$ & $39^{* *}$ & $60^{* *}$ & $64^{* *}$ & $61^{* * *}$ & $45^{\text {** }}$ & $43^{*}$ \\
\hline $\mathrm{A} \times \mathrm{S}$ & --- & --- & --- & 9 & 9 & 10 & $22^{*}$ & 17 & 19 & 4 & 8 & 7 & 3 & 6 & 16 \\
\hline Error & 0 & 9 & 6 & 66 & 18 & 33 & 33 & 49 & 38 & 50 & 31 & 26 & 30 & 48 & 40 \\
\hline
\end{tabular}

${ }^{\mathrm{z}} \mathrm{L}=$ large ( $\left.>13 \mathrm{~mm}\right), \mathrm{M}=$ medium $(8$ to $13 \mathrm{~mm})$, and $\mathrm{S}=$ small $(<8 \mathrm{~mm})$.

y Means with different letters in columns are significantly different by LSD at $P=0.05$.

${ }^{\mathrm{x}} \mathrm{Sum}$ of squares for each factor converted to a percentage of total sum of squares.

Ns,*,** Nonsignificant or significant at $P=0.05$ or 0.01 , respectively.

(Table 3). From 1990 to 1992, the effect of harvest season was the dominant factor affecting stands.

In 1989, the 30-month-old plants were harvested for the first time and the 18-month-old plants were harvested for the second time. Delaying first harvest to 30 vs. 18 months initially maintained better stands through 1991, but, by 1992, stand loss was unaffected by timing of first harvest (Table 3). From 1990 to 1992,

Table 3. Influence of harvest season and age at first harvest on stand from 1989 to 1992.

\begin{tabular}{|c|c|c|c|c|c|}
\hline \multirow{2}{*}{$\begin{array}{l}\text { Harvest } \\
\text { season }\end{array}$} & \multicolumn{4}{|c|}{ Plants/plot } & \multirow{2}{*}{$\begin{array}{l}\text { Plant loss } \\
\text { (\%) from } \\
1986-92\end{array}$} \\
\hline & 1989 & 1990 & 1991 & 1992 & \\
\hline Spring & 35 & $32 a^{z}$ & $31 \mathrm{ab}$ & $21 \mathrm{bc}$ & $48 \mathrm{bc}$ \\
\hline May & 33 & $27 \mathrm{~b}$ & $24 \mathrm{c}$ & $9 \mathrm{~d}$ & $78 \mathrm{a}$ \\
\hline June & 33 & $30 \mathrm{a}$ & $30 \mathrm{ab}$ & $21 \mathrm{c}$ & $49 \mathrm{~b}$ \\
\hline July & 33 & $31 \mathrm{a}$ & $30 \mathrm{ab}$ & $25 \mathrm{abc}$ & $37 \mathrm{bcd}$ \\
\hline August & 33 & $30 \mathrm{a}$ & $29 a b$ & $28 \mathrm{a}$ & $31 \mathrm{~d}$ \\
\hline September & 34 & $33 \mathrm{a}$ & $32 \mathrm{a}$ & $30 \mathrm{a}$ & $28 \mathrm{~d}$ \\
\hline October & 33 & $30 \mathrm{a}$ & $28 \mathrm{~b}$ & $28 \mathrm{a}$ & $31 \mathrm{~d}$ \\
\hline Unharvest & 34 & $32 \mathrm{a}$ & $31 \mathrm{ab}$ & $27 \mathrm{ab}$ & $34 \mathrm{~cd}$ \\
\hline \multicolumn{6}{|c|}{ Age (months) at first harvest } \\
\hline 18 & $33 a$ & $29 \mathrm{a}$ & $28 \mathrm{a}$ & NS & NS \\
\hline 30 & $35 \mathrm{~b}$ & $32 \mathrm{~b}$ & $30 \mathrm{~b}$ & NS & NS \\
\hline \multicolumn{6}{|c|}{ Source of variation ${ }^{y}$} \\
\hline Rep & $20^{* *}$ & $20^{* *}$ & $22^{* *}$ & 4 & 4 \\
\hline Age (A) & $12^{* *}$ & $13^{* * *}$ & $7^{* *}$ & 1 & 1 \\
\hline Season $(\mathrm{S})$ & 8 & $22^{*}$ & $34^{* *}$ & $61^{* * *}$ & $61^{* * *}$ \\
\hline$A \times S$ & 16 & 9 & 9 & 10 & 9 \\
\hline Error & 44 & 36 & 28 & 24 & 25 \\
\hline
\end{tabular}

${ }^{\mathrm{z}}$ Means with different letters in columns are significantly different by LSD at $P=0.05$.

ySum of squares for each factor converted to a percentage of total sum of squares.

Ns, ${ }^{*},{ }^{* *}$ Nonsignificant or significant at $P=0.05$ or 0.01 , respectively. stands in May forcing plots were lower than all other harvest seasons. By 1992, harvest stress from May forcing and spring harvesting reduced stands $78 \%$ and $48 \%$, respectively. August to October forcings were less stressful to recovery than May and June forcings and spring harvesting.

Harvest season vs. plants' ability to reach cutting pressure. The inability of a plant to reach cutting pressure $(\mathrm{CP})$ during the harvest season is another indicator of dwindling vigor affecting recovery and subsequent harvests in following years. A major portion of the variation in this variable was assigned to age in 1989, but this effect diminished in following years (Table 4). In 1989, fewer plants reached the prescribed CP if harvested for the first time 18 months after transplanting in their second harvest season than plants harvested for the first time 30 months after transplanting. Delaying first harvests to 30 months after transplanting was unwarranted.

Harvest season greatly affected ability to reach CP. In 1989, $\approx 83 \%$ of all plants forced from May through August reached CP by the harvest season's end (September excluded because of Hurricane Hugo damage) (Table 4). In comparison, $51 \%$ of spring-harvested and $16 \%$ of October-forced plants reached CP within the prescribed time limit. Cooler temperatures during these times reduced emergence, while warmer summer months accelerated emergence. Adverse effects of forcing became more pronounced after 1990. From 1990 to $1992,>80 \%$ of all variation in emergence ability was due to harvest season. Less than $30 \%$ of spring-harvested plants reached $\mathrm{CP}$ by harvest termination during these years. By 1992, May forcing proved highly stressful, with only $13 \%$ of plants reaching CP. The greater yields in July and August 1992 forcings were a direct result of more plants reaching $\mathrm{CP}$ by harvest termination. Cooler seasonal temperatures in spring and October were responsible for significantly fewer plants achieving $\mathrm{CP}$.

Fern biomass vs. harvest season. Fern biomass production just before fern mowing and forcing indicated plant vigor and recovery ability from the rigors of the previous year's harvest. Most variation in stalk number and weight in 1989 was assigned to age at first 
harvest (Table 5). Plants first harvested 18 months after transplanting produced more stalks of lower weight than those harvested 30 months after transplanting. Plant age at first harvest interacted with harvest season, affecting fern weight per plant and individual fern weight. Fern weighed more in May and June forcings if first harvest was delayed to 30 months after transplanting (data not shown). In contrast, fern weighed the same regardless of age at first harvest in July through September forcings. By 1990, however, the main effect of age and age $\times$ season interactions diminished and

Table 4. Influence of harvest season and age at first harvest on the percentage of plants not to reach cutting pressure by harvest season's termination from 1989 to 1992.

\begin{tabular}{lcccc}
\hline \hline Harvest & \multicolumn{4}{c}{ Plants not reaching cutting pressure (\%) } \\
\cline { 2 - 5 } season & 1989 & 1990 & 1991 & 1992 \\
\hline Spring & $49 \mathrm{~b}^{\mathrm{z}}$ & $76 \mathrm{a}$ & $73 \mathrm{~b}$ & $77 \mathrm{~b}$ \\
May & $22 \mathrm{c}$ & $41 \mathrm{c}$ & $41 \mathrm{c}$ & $87 \mathrm{~b}$ \\
June & $16 \mathrm{c}$ & $12 \mathrm{f}$ & $26 \mathrm{~d}$ & $24 \mathrm{c}$ \\
July & $14 \mathrm{c}$ & $19 \mathrm{ef}$ & $31 \mathrm{~d}$ & $20 \mathrm{c}$ \\
August & $16 \mathrm{c}$ & $35 \mathrm{~cd}$ & $41 \mathrm{c}$ & $18 \mathrm{c}$ \\
September & $---^{\mathrm{y}}$ & $29 \mathrm{de}$ & $46 \mathrm{c}$ & $27 \mathrm{c}$ \\
October & $84 \mathrm{a}$ & $63 \mathrm{a}$ & $98 \mathrm{a}$ & $100 \mathrm{a}$ \\
Age (months) at first harvest & & & \\
18 & $43 \mathrm{a}$ & $\mathrm{NS}$ & $\mathrm{NS}$ & $\mathrm{NS}$ \\
30 & $24 \mathrm{~b}$ & $\mathrm{NS}$ & $\mathrm{NS}$ & $\mathrm{NS}$ \\
Source of variation & & & & \\
Rep & 1 & 1 & 0 & 0 \\
Age (A) & $81^{* * *}$ & 0 & 0 & 0 \\
Season (S) & $12^{* *}$ & $83^{* *}$ & $88^{* *}$ & $93^{* *}$ \\
A $\times$ S & 1 & 4 & $5^{* *}$ & 0 \\
Error & 5 & 12 & 7 & 7 \\
\hline
\end{tabular}

${ }^{\overline{\mathrm{z}} \text { Means with different letters in columns are significantly different by LSD }}$ at $P=0.05$.

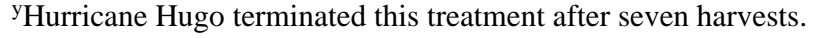

${ }^{\mathrm{x}}$ Sum of squares for each factor converted to a percentage of total sum of squares.

Ns, ${ }^{*}, * *$ Nonsignificant or significant at $P=0.05$ or 0.01 , respectively. only harvest season accounted for the major source of variation with all biomass variables.

The number of stalks produced per plant before mowing increased from 1988 to 1990 as forcing season was delayed from May to September (Table 5). By 1991, fern biomass was greater in June through August forcings than in September and October forcings, but May forcing severely reduced fern vigor.

Storage root carbohydrates vs. harvest season. Low carbohydrate status in the crowns causes poor plant performance. Excessive harvest pressure depletes carbohydrates and becomes cumulative as harvest years pass. The carbohydrate levels in the unharvested and spring-harvested controls can be used to compare all other forcing treatments. Figure 3 summarizes the yearly mean fructose level (pooled mean of 31 sampling dates throughout the 5year period) by harvest season.

Carbohydrate levels in all harvest seasons decreased from 1988 to 1992, including the unharvested control. The greatest decline in carbohydrates in all treatments occurred from 1990 to 1992. By 1992, May carbohydrate levels were lowest of all harvest seasons and explained the reported poor vigor, stands, and yields. Carbohydrate levels increased as forcing time progressed through September, but decreased by October forcing. Carbohydrate levels in July through September forcing tended to be higher than in the spring and unharvested controls. This suggested that forcing at these times is no more stressful than normal spring harvesting and that adequate time elapsed for carbohydrate replenishment in the crowns after harvesting.

\section{Discussion}

Plant productivity and longevity were inherent problems in the normal spring production of ' $\mathrm{UC} 157 \mathrm{~F}_{1}$ ' asparagus. Although first year yields were greatest with spring asparagus, yield progressively declined over the 5-year period. Spring yields by 1992 were unacceptable. Spring asparagus production with this cultivar had only a 4-year lifespan which is too short to be commercially appealing; however, other cultivars may be more suitable for spring and forcing production. The yield decline plaguing 'UC 157

Table 5. Influence of harvest season and age at first harvest on fern vigor.

\begin{tabular}{|c|c|c|c|c|c|c|c|c|c|}
\hline \multirow{3}{*}{$\begin{array}{l}\text { Harvest } \\
\text { season }\end{array}$} & \multicolumn{9}{|c|}{ Fern biomass before first harvest } \\
\hline & \multicolumn{3}{|c|}{ Stalks/plant } & \multicolumn{3}{|c|}{$\mathrm{Wt}(\mathrm{g}) / \mathrm{plant}$} & \multicolumn{3}{|c|}{ Individual fern wt (g) } \\
\hline & 1989 & 1990 & 1991 & 1989 & 1990 & 1991 & 1989 & 1990 & 1991 \\
\hline May & $4 \mathrm{e}^{\mathrm{z}}$ & $9 \mathrm{bc}$ & $4 \mathrm{~d}$ & $453 \mathrm{~b}$ & $536 \mathrm{a}$ & $144 \mathrm{~b}$ & $115 \mathrm{a}$ & $59 \mathrm{~b}$ & $40 \mathrm{c}$ \\
\hline June & $6 \mathrm{~d}$ & $9 \mathrm{bc}$ & $9 \mathrm{ab}$ & $460 \mathrm{~b}$ & 789 a & 496 a & $78 \mathrm{~b}$ & 89 a & $57 \mathrm{~b}$ \\
\hline July & $9 \mathrm{c}$ & $13 \mathrm{a}$ & $10 \mathrm{a}$ & $710 \mathrm{a}$ & $755 \mathrm{a}$ & 546 a & $82 \mathrm{~b}$ & $60 \mathrm{~b}$ & $53 \mathrm{bc}$ \\
\hline August & $11 b$ & $14 \mathrm{a}$ & $9 \mathrm{ab}$ & $697 \mathrm{a}$ & $686 \mathrm{a}$ & $462 \mathrm{a}$ & $64 \mathrm{bc}$ & $51 \mathrm{~b}$ & $52 \mathrm{bc}$ \\
\hline September & $13 \mathrm{a}$ & $12 \mathrm{ab}$ & $8 \mathrm{bc}$ & $486 \mathrm{~b}$ & $724 \mathrm{a}$ & 592 a & $39 \mathrm{c}$ & $62 \mathrm{~b}$ & $78 \mathrm{a}$ \\
\hline October & $---^{y}$ & $8 \mathrm{c}$ & $7 \mathrm{c}$ & --- & $672 \mathrm{a}$ & 536 a & --- & $88 \mathrm{a}$ & $77 \mathrm{a}$ \\
\hline \multicolumn{10}{|c|}{ Age (months) at first harvest } \\
\hline 18 & $9 \mathrm{a}$ & NS & NS & $463 \mathrm{a}$ & NS & NS & $54 \mathrm{a}$ & $63 \mathrm{a}$ & NS \\
\hline 30 & $8 \mathrm{~b}$ & NS & NS & $649 b$ & NS & NS & $98 \mathrm{~b}$ & $73 \mathrm{~b}$ & NS \\
\hline \multicolumn{10}{|c|}{ Source of variation ${ }^{\mathrm{x}}$} \\
\hline Rep & $3 *$ & 1 & 2 & 1 & 2 & 1 & 5 & 1 & 0 \\
\hline Age (A) & $84^{* * * *}$ & 1 & 0 & $37^{* * *}$ & 2 & 0 & $32^{* *}$ & 6 & 0 \\
\hline Season $(\mathrm{S})$ & $4^{* *}$ & $44^{* * *}$ & $71^{* *}$ & $21^{* *}$ & 22 & $63^{* *}$ & $25^{* *}$ & $58^{* * *}$ & $59^{* *}$ \\
\hline $\mathrm{A} \times \mathrm{S}$ & 1 & 4 & 2 & $19 *$ & 18 & 7 & $22^{* *}$ & 9 & 11 \\
\hline Error & 8 & 50 & 25 & 22 & 56 & 30 & 16 & 26 & 30 \\
\hline
\end{tabular}

${ }^{\mathrm{z}}$ Means with different letters in columns are significantly different by LSD at $P=0.05$.

'Hurricane Hugo destroyed existing fern on 19 Sept. 1989.

${ }^{\mathrm{x}}$ Sum of squares for each factor converted to a percentage of total sum of squares.

Ns,*,**,*** Nonsignificant or significant at $P=0.05,0.01$, or 0.001 , respectively. 


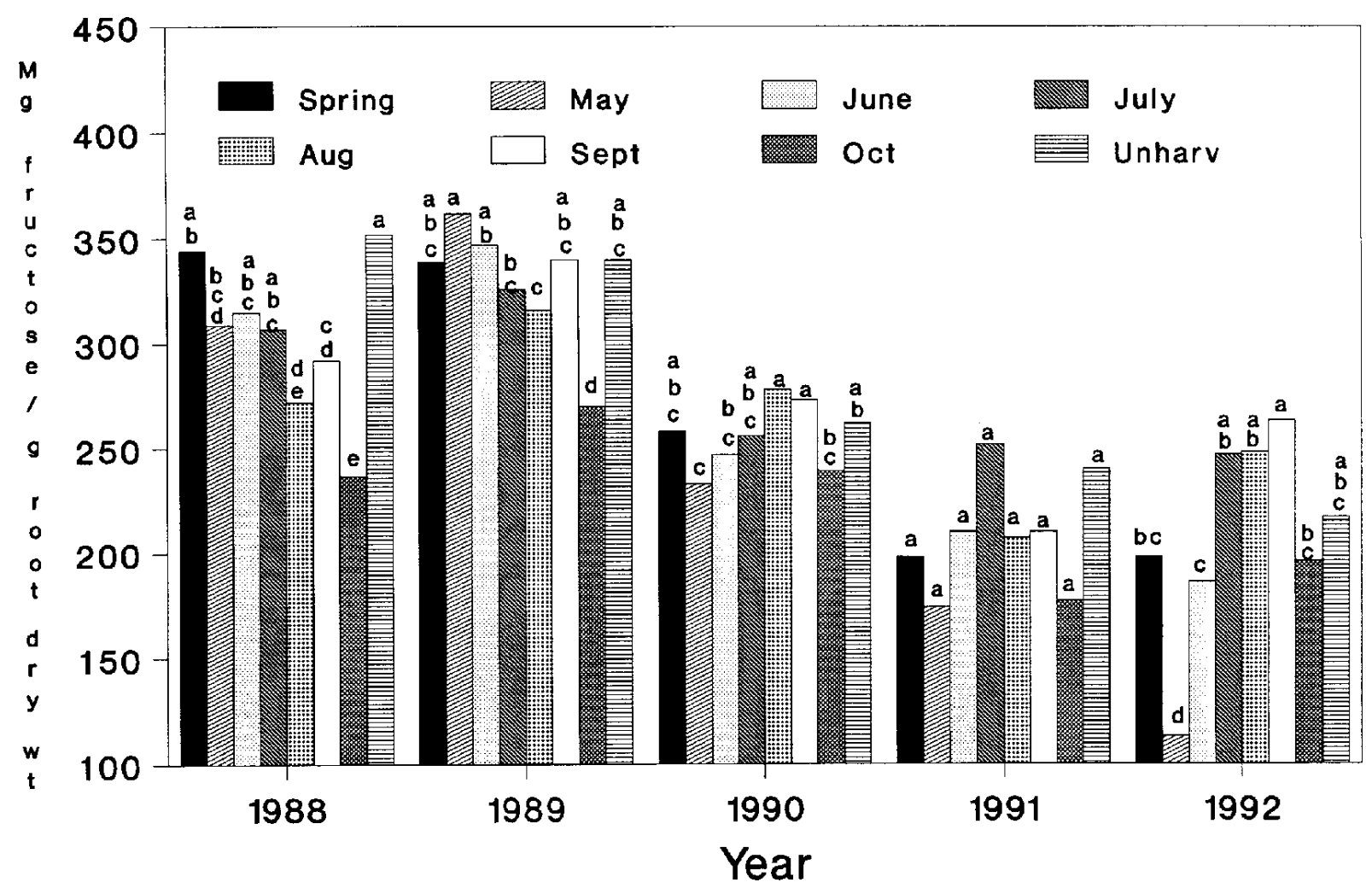

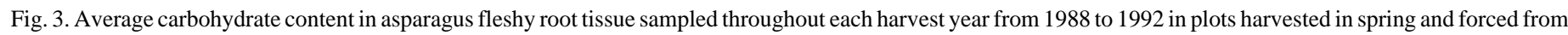
May to October. Bars within each year with different letter are significant by LSD at $P=0.05$.

$\mathrm{F}_{1}$ ' spring asparagus production may be an artifact of climate. During spring production, inherently lower soil temperatures than in the summer prevented $>70 \%$ of the plants from 1990-92 from reaching the prescribed cutting pressure by harvest season's end, thereby drastically reducing yield potential. These results in the field are similar to those reported in greenhouse trials (Dufault, 1991). Yields may have been improved by allowing longer spring harvest seasons and terminating harvest by spear diameter criteria rather than by strict time limits. The capacity of fern in springharvested plots to elaborate carbohydrates after harvest may have declined in mid-summer, rendering the fern less efficient than fern produced after July harvests. Photosynthetic rates of asparagus fern reach highest levels 3 months after emergence but decline to the lowest level after 5 months (Hung, 1980).

Summer forcing in either July or August produced acceptable yields through 1992 and forcing seems to be a more viable production system than spring harvesting. Although summerforced yields were less than the national per-hectare average, the value and supply of fresh-market asparagus during late summer makes summer production more desirable and profitable than spring production. Crown carbohydrate levels were similar between July forcing and spring harvesting, even though the latter had longer periods after the harvest season to recover and produce fern. July-forced plants may have stored more carbohydrates during spring when left unharvested than spring-harvested plants (Dufault, 1991).

Total productivity was superior with July and August forcing seasons. Adequate time elapsed from spring until fern mowing, improving fern vigor and recovery from carbohydrate drain from spring fern production. More than $70 \%$ of plants forced in July and August reached prescribed cutting pressure, and this increased yield potential. Summer-forced plants were exposed to greater harvest pressures, and this may have stimulated spear emergence (Dufault, 1991). Kretschmer and Hartmann (1979) reported that more frequent harvesting induces an increase of spear emergence. Summer forcing may have encouraged release of apical dominance and production of more efficient fern after the harvest season, since crown carbohydrate levels were higher in July and August forcings than in spring-harvested plants.

Forcing in May or June was detrimental to yield, since recovery ability and stands were significantly reduced. Spring fern growth before fern mowing in either May or June forcings decreased crown carbohydrate levels. Fern mowing to force production in May or June removed the source of carbohydrate synthesis (fern) and induced great demands on sink (crown) at already low carbohydrate status. Yearly repetition of these stresses eventually reduced plant vigor and stands by 1990 in May forcing and by 1992 in June forcing.

Temperatures by October forcings inhibited spear emergence to the degree that eliminated this forcing time completely from commercial adaptation. On the other hand, forcing in September has some potential for use, but its value depends on seasonal temperatures remaining warm enough to enhance budbreak and emergence. Enough time elapsed from spring to September for fern growth to replenish crown carbohydrates before forcing began again in September. Since the price of fresh-market asparagus continues to increase throughout the fall, in spite of lower yields, the unit value for September forced asparagus is higher than earlier forcing.

Age of asparagus plants at first harvest was not considered to be important with spring or summer forcing in our area. Tropical summers and subtemperate winters provide very long growing seasons for new asparagus plantings. The growth of 18-month-old asparagus plants in this climate has been observed to be equal to 
plants twice that age in more northern temperate climates.

\section{Conclusion}

Forcing asparagus into production from July through September has greater potential for higher economic value and long-term survival than normal spring harvests in coastal South Carolina. First harvests should begin 18 months after transplanting in fall. Delaying first harvests for 30 months does not increase long-term plant vigor, stands, or yields. Further work should evaluate more suitable cultivars for southern climates. Also, work is needed to study summer cutting pressure and incorporating the technique of mother stalk culture developed in the tropics into present forcing techniques (Wang, 1970).

\section{Literature Cited}

Benson, B. and J. Motes. 1982. Influence of harvesting asparagus the year following planting on subsequent yield and quality. HortScience 17:744745.

Brasher, E.P. 1956. Effects of spring, summer, and fall cutting of asparagus on yield and spear weight. Proc. Amer. Soc. Hort. Sci. 67:377-383.

Campbell Institute of Agricultural Research. 1970. Twice-a-year harvesting of asparagus. HortScience 5:512.

Cook, W. 1977. Agricultural chemicals handbook. Clemson Univ. Coop. Ext. Serv. EC 670.

Dufault, R. 1991. Response of spring and summer-harvested asparagus to harvest pressures. HortScience 26:845-847.

Dufault, R. 1994. Relationship between soil temperature and spring asparagus spear emergence and quality in coastal South Carolina. Acta. Hort. (In press.)

Farish, L.R. 1937. Fall cuttings of asparagus compared with spring cuttings under Mississippi conditions. Proc. Amer. Soc. Hort. Sci. 35:693-695.

Hung, L. 1980. Special aspect of asparagus growing in Taiwan. Chinese Soc. Hort. Sci. 26:1-10.

Jasmin, J. and J. Laliberte. 1962. Note on fall cutting of asparagus on organic soils in southwestern Quebec. Can. J. Plant Sci. 42:737-738.

Jenkins, J. 1959. Asparagus cutting experiment. Amer. Veg. Grower 7(3):38.

Jones, H. and W. Robbins. 1926. Influence of cutting asparagus the first year after planting on production the following year. Proc. Amer. Soc. Hort. Sci. 23:23-25.

Kretschmer, M. and H. Hartmann. 1979. Experiments in apical dominance with Asparagus officinalis L, p. 235-239. In: G. Reuther. (ed.). Proc. 5th Intl. Asparagus Symp., Eucarpia, Geisenheim, West Germany.

Lewis, E. 1934. Asparagus yields as affected by severity of cutting. Illinois Agr. Expt. Sta. Bul. 401:25-36.

Lloyd, J. and J. McCollum. 1938. Yields of asparagus as affected by severe cutting of young plantations. Illinois Agr. Expt. Sta. Bul. 448:157-172.

Morris, D.L. 1948. Quantitative determination of carbohydrates with Dreywood's anthrone reagent. Science 107:254-255.

Scott, L., J. Mitchell, and R. McGinty. 1939. Effects of certain treatments on the carbohydrate reserves of asparagus crowns. South Carolina Agr. Expt. Sta. Bul. 321.

Shelton, D. and M. Lacy. 1980. Effect of harvest duration on yield and on depletion of storage carbohydrates in asparagus roots. J. Amer. Soc. Hort. Sci. 105:332-335.

U.S. Department of Agriculture. 1977. United States standards for grades of fresh asparagus. U.S. Dept. of Agr. Food Safety and Quality Serv., Washington, D.C

Wang, C.S. 1970. Studies on "Mother stalk method" of asparagus harvesting. 2nd Rpt. J. Chinese Soc. Hort. Sci. 16:16-23. 